\title{
Influence of Students' Engagement with Social Networks on their Study Habits and Cognitive Skills in Science Classrooms
}

\author{
A.M. Oginni, S.O. Saibu, V.Y. Awobodu, M.O. Alaka \\ Adeniran Ogunsanya College of Education, Otto, Ijanikin, Lagos
}

\begin{abstract}
Social networks are becoming an integral part of our lives. They have revolutionized the way we communicate, interact and socialize. Students are considered the largest categories that use these applications as millions of them are spending many hours on social networking sites like Facebook, Twitter, Youtube, Whats App, Tango and so on. This study examines the influence of students' engagement with social networks on their study habits and cognitive skills in science classrooms in secondary schools in Education District VI, Lagos State, Nigeria using a survey questionnaire to collect information from a sample of one hundred (100) senior secondary school students. Chi square using Statistical Packages for Social Sciences (SPSS) at .05 significance alpha level was adopted to analyze the stated hypotheses. The study findings revealed that the use of social networks have significant impact on students' attitudes, their study habits and cognitive skills in science classrooms. The study recommended that students should be enlightened on the benefits and limitations of using social networks for both academic and leisure.
\end{abstract}

\section{Introduction}

Social networks are the main application under the umbrella of social media, which come with the Web 2.0 era. They cover all about engagement creating relationship, communicating with one's readers, building his following and connecting with his online audiences. Social networking started in the 90s, where Chat Rooms and Bulletin Board System (BBS) were forms of connecting with one another and to share interest. The first recognizable social network site which was launched in 1997, "sixegrees.com" allows users to create profile, list their friends and beginning in 1998, surf the friend list. Between this period and 2004, many social network sites came into existence such as Friendster, Myspace, Facebook and so on but Facebook emerge and grew rapidly in 2007, [1]. At first Facebook was solely for college and high school students but in recent time we have witnessed the development of more social media platforms for online social networking like twitter, Google+, Instagram, Whats app, Messenger, Tango and others and this has expanded the level of networking and increased the use of social media for both private and corporate purposes [2].

Recent trends have shown that social network services provide opportunities within professional education, curriculum education and learning [3]. Today teenagers show very much interest in using all these social networks for different purposes such as access to information, group discussion, resource sharing and entertainment. As several studies demonstrate, social media interaction could have both positive and negative effects on students.

In spite of the opportunities social networking has for mankind; it is observed that the total attention and concentration of students have been diverted towards non education, unethical and inappropriate actions such as useless chatting through the use of mobile phones and devices within the school premises. The negative impact of social networking on the students is also being traced to the fact that students make use of these devices when teaching is going on. Also at their respective homes, they spend great deal of time on social networking activities leaving their studies to a deterring state which may have adverse effect on their academic performances. Studies from literatures show that social networking media has gained considerable attention as a factor affecting students' academic performance [4-7].

Browsing the net, playing games online and passing non-stop SMSs seem to be their daily routine, making reading books or any other written materials an outdated idea for most school children. In fact, students see social network sites as platforms to make friends who can always take them out of boredom. So instead of using social network sites to source for relevant information that will help them in their studies, they just pay attention to their chats and while away their time [8]. Most importantly, the provision virtual life to students by social networks helps those who do not have the confidence to speak in front of anyone now feel free to interact confidently in their virtual life. When they use these social networks, they feel like in heaven but this addition kills their inner self confidence forever. Becoming addicted to social networks make them feel like they have so many friends but in real, all of the contacts they communicate with are virtual contacts. The frequent use of these social networks could cause addiction toward the site and influence students' daily life at large [9].

Al-Shargi, Hashim and Kutbi [10] assert that Liu [11] studied students' use, attitudes and perceptions of 16 different social media tools through an online questionnaire involving 221 students. The top four reasons that prompted students' use of social media tools were found to be social engagement $(85 \%)$, direct communications (56\%), speed of 
feedback/results (48\%), and relationship building $(47 \%)$.

Al-Tarawneh [12] emphasizes that in education, two streams are prevailing for social networks: the use of social networks as a tool supporting activities deemed important for the purpose of educational institutions, instructors, and students. The second stream is the bad influence social network inflicts on students behaviours and time management. According to Wang, Chen and Liang [13] students use social network sites for many purposes such as access to information, group discussion, resource sharing and entertainment.

Social networking has only one goal. It is to encourage new ways to communicate and share information. Observations showed, however, that many students have been blaming various social networking for their negative effects on the students study habits and steady decrease in their grade point averages [14].

It is against this background that the study investigates the influence of students' engagement with social networks on the study habits and cognitive skills of secondary school science students in Education District VI, Lagos State, Nigeria.

\section{Research Questions}

Therefore, the study sought to answer the following questions.

- What is the level of students' attitude towards using social networks in science classrooms?

- How has the use of social networks imparted on students' study habit in science?

- Do social networks affect students' learning outcome in science classrooms?

\section{Hypotheses}

The following hypotheses were formulated to guide the study.

- Social networks have no significant impact on students' attitude in science classrooms.

- Social networks will not significantly affect students' study habits in science classrooms.

- The uses of social networks have no significant impact on students' cognitive skills in science classrooms.

\section{Methodology}

The study adopted a descriptive survey research design. The population consisted of all science students in senior secondary schools in Lagos State Education District VI, Nigeria. Using simple random sampling technique, a total of one hundred
(100) science students were selected from five senior secondary schools in the District. Meanwhile, twenty (20) students were selected from each of the sampled schools.

The instrument used for data collection was a self-developed questionnaire by the researchers and validated by five science and computer educators. The questionnaire contained fifteen (15) items whose responses were structured on a Four Likert Scale System of Strongly Agreed (SA), Agreed (A), Disagree (D), and Strongly Disagree (SD). In developing the questionnaire instrument, questions were adapted from the existing instrument of similar research carried out by the researchers to suit the study.

The reliability of the questionnaire was determined by using split-half reliability method and Pearson Product Moment (PPM) correlation formula was used to determine the reliability index which yielded a coefficient of 0.87 . This is adjudged as been reliable.

\section{Findings and Results Analysis}

As presented in the methodology section, the questionnaire has been subjected to quantitative analysis using simple percentage and Chi Square processed through Statistical Package for the Social Sciences (SPSS) software. This forms the basis for testing the hypotheses formulated to guide the study. Meanwhile, the data were arranged in figures and tabulated based on each of the hypotheses as indicated below.

Hypothesis 1: Social networks have no significant impact on students' attitude in science classrooms.

Table 1. Social networks influence on students' attitudes in science classrooms $(n=100)$

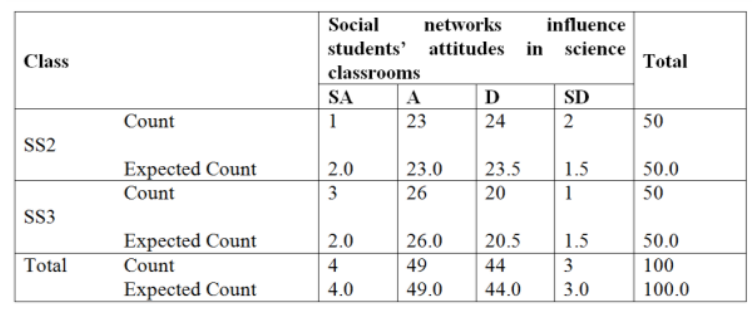

Table 1 shows the responses of the students to the influence of social networks on students' attitudes in science classrooms. As seen here, it is clear that $53 \%$ of the students agreed that social networks affect students' attitudes towards learning in science classrooms. This can be in form of causing lots distraction to students in the classroom while lessons are ongoing. Thus, $47 \%$ of the students disagreed. 
Table 2.Chi-square Test

\begin{tabular}{|l|l|l|l|}
\hline & Value & Df & Asymp. Sig. (2-sided) \\
\hline Pearson Chi-Square & $6.355 \mathrm{a}$ & 3 & .003 \\
Likelihood Ratio & 1.408 & 3 & .704 \\
Linear-by-Linear Association & .635 & 1 & .426 \\
\hline
\end{tabular}

In line with Table 1, a Pearson Chi-square Test was conducted to find the influence of social networks on students' attitude in science classrooms. Table 2 shows that there is significant impact of social networks on students' attitude in science classrooms. [Chi-square $=6.355, \mathrm{df}=3, \mathrm{p}<.05]$. This implies that social networks fosters negative attitude among students in science classrooms.

Hypothesis 2: Social networks will not significantly affect on students' study habits in science classrooms.

Table 3. Influence of social networks on students' study habits in science classrooms $(n=100)$

\begin{tabular}{|c|c|c|c|c|c|c|}
\hline \multirow[t]{2}{*}{ Class } & & \multicolumn{4}{|c|}{$\begin{array}{|lrrr|}\begin{array}{l}\text { Social } \\
\text { study hetwork } \\
\text { habits } \\
\text { classrooms }\end{array} & \begin{array}{r}\text { and } \\
\text { in }\end{array} & \begin{array}{r}\text { students' } \\
\text { science }\end{array} \\
\end{array}$} & \multirow[t]{2}{*}{ Total } \\
\hline & & SA & A & D & SD & \\
\hline \multirow{2}{*}{ SS2 } & Count & 1 & 28 & 20 & 1 & 50 \\
\hline & Expected Count & 2.0 & 28.0 & 29.5 & 1.0 & 50.0 \\
\hline \multirow{2}{*}{ SS3 } & Count & 2 & 28 & 20 & 1 & 50 \\
\hline & Expected Count & 1.5 & 28.0 & 29.5 & 1.0 & 50.0 \\
\hline Total & $\begin{array}{l}\text { Count } \\
\text { Expected Count }\end{array}$ & $\begin{array}{l}3 \\
3.0\end{array}$ & \begin{tabular}{|l|}
56 \\
56.0
\end{tabular} & $\begin{array}{l}39 \\
39.0\end{array}$ & $\begin{array}{l}2 \\
2.0\end{array}$ & $\begin{array}{l}100 \\
100.0\end{array}$ \\
\hline
\end{tabular}

Table 3 illustrates the effects of social networks on students' study habits in science classrooms. It depicts that $59 \%$ of the respondents agreed that social networks have effects on students' study habits in science classrooms. Their responses showed that majority of the students often spend most of their useful time on social networks rather reading. Meanwhile $41 \%$ of the respondents believed that social networks have nothing to do with the study habits of students in science.

Table 4. Chi-square Test

\begin{tabular}{|l|l|l|l|}
\hline & Value & Df & Asymp. Sig. (2-sided) \\
\hline Pearson Chi-Square & 8.399 & 3 & .007 \\
Likelihood Ratio & .365 & 3 & .947 \\
Linear-by-Linear Association & .116 & 1 & .733 \\
\hline
\end{tabular}

A Pearson Chi-square Test was conducted on Table 3 to find the influence of social networks on students' study habits in science classrooms. The analysis on Table 4 reveals that there is significant impact of social network on students' study habits in science classrooms (Chi-square $=8.359, \mathrm{df}=3, \mathrm{p}<$ $.05)$.

Hypothesis 3: The uses of social networks have no significant impact on students' cognitive skills in science classrooms.
Table 5. Social network and students' cognitive skills in science classrooms

\begin{tabular}{|c|c|c|c|c|c|c|}
\hline \multirow[t]{2}{*}{ Class } & & \multicolumn{4}{|c|}{$\begin{array}{l}\text { Social network on students } \\
\text { learning outcome in science } \\
\text { classrooms }\end{array}$} & \multirow[t]{2}{*}{ Total } \\
\hline & & SA & A & D & SD & \\
\hline \multirow{2}{*}{ Sss 2} & Count & 0 & 26 & 22 & 2 & 50 \\
\hline & Expected Count & 1.0 & 25.0 & 22.5 & 1.5 & 50.0 \\
\hline \multirow{2}{*}{ SSs 3} & Count & 2 & 24 & 23 & 1 & 50 \\
\hline & Expected Count & 10 & & 225 & 15 & 500 \\
\hline Total & $\begin{array}{l}\text { Count } \\
\text { Expected Count }\end{array}$ & $\begin{array}{l}2 \\
2.0\end{array}$ & $\begin{array}{l}50 \\
50.0\end{array}$ & \begin{tabular}{|l|}
45 \\
45.0
\end{tabular} & \begin{tabular}{|l|}
3 \\
3.0
\end{tabular} & $\begin{array}{l}100 \\
100.0\end{array}$ \\
\hline
\end{tabular}

Data analysis in Table 5 shows that $52 \%$ of the respondents agreed that social networks affect students' cognitive skills in science classrooms. They believed that students do not use social networks to get additional information on topics learnt in science lessons and also social networks prevent students from revising the lessons taught in science classes. Meanwhile $48 \%$ of the respondents disagreed that social networks could lead to poor learning outcome of students in science classrooms.

Table 6. Chi-square Test

\begin{tabular}{|l|l|l|l|}
\hline & Value & Df & Asymp. Sig. (2-sided) \\
\hline Pearson Chi-Square & $7.436 \mathrm{a}$ & 3 & .001 \\
Likelihood Ratio & 3.215 & 3 & .360 \\
Linear-by-Linear Association & .225 & 1 & .614 \\
\hline
\end{tabular}

A chi-square Test was conducted to find the impact of social networks on student learning outcome in science classrooms. The analysis in Table 6 depicts that the use of social network has significant impact on students' learning outcomes in science classrooms $($ Chi-square $=7.436, \mathrm{df}=3, \mathrm{p}<.05)$.

\section{Discussion of Results}

The three hypotheses formulated for the study were rejected. These show that social networks that are supposed to have positive influence on students' attitude, their study habits and cognitive skills have brought great setback to most of the students.

In a study exploring how students use social media, Wang, Chen and Liang [13] report that most college students spent vast number of hours accessing social media sites. Ninety percent of students surveyed spent their time on entertainment. While eighty percent of the sample admitted that they posted or responded while completing homework, not too many college students preferred using social media to do their homework. Considering the overall results of collected data analysis, there was a negative attitude towards social media when college students used them. The analysis also indicates that an approach is needed to better balance the relationship between social media and academic study. This finding is also congruent to that of Korzney [15] and Oginni et al. [16] who assert that social networking 
grabs the total attention and concentration of the students, and diverts them towards non education, unethical and inappropriate actions such as useless chatting.

More so, the habit of studying is decreasing day by day among the students resulting to poor academic performance. Students prefer to spend hours browsing on the net for unnecessary sites, playing games and passing non-stop SMSs through 2 go, Instagram, Facebook, tango and so on. They no longer use social network sites to source for relevant information that will help them in their studies but pay more attention to chatting and while away their precious time [8]. According to Hay [17], the more time spent on social networking sites, the less they may be good for students' social lives, in the way that it may cause them to be more illiterate; short forms, and even the limited amount of characters one is allowed to type on certain statuses, don't help expand the writing portion of a student's mind resulting in lower grade averages and less time spent on studies.

Studies by Ibrahim [18] and Oginni et al. [16] show that the academic performances of students are facing a lot of neglect and challenges because of different networks students are exposed to. These different networks have taken a firm power over human's lives in this modern world. Social networks today have not greatly contributed to the learning outcome of students because technology has made things easy for everybody and the students seem not to understand this and how purposefully they can use these network sites for their academic excellence, hence they have poor performance in their learning outcome. In contrast, Social networking sites have the potential to make learning more student centered [19].

\section{Conclusion}

The primary purpose of the study was to examine the influence of students' engagement with social networks on their study habits and cognitive skills in science classrooms. The findings indicated that students are influenced to a great extent by the social networks negatively because their attention is focused on chatting and music while their academic activities are neglected and left to suffer. Students are supposed to use the social networking sites as a supplementary to the curriculum but the prevalence and continuous engagement of students in online social networks continued to be on increase, thereby imparting negatively on their academic excellence.

In view of this, students should be trained and enlightened on how to make full use of social networks and other technological devices in their learning activities in order to ensure accountability in and outside the class. Schools, teachers and educational manager should integrate teaching and learning of science subjects into social network sites by creating academic groups where students will be mandated to join for the purpose of distributing and circulating course materials, projects, exercises etc. This will go a long way in keeping the students busy and making them spend their time judiciously well on positive events and academic activities.

\section{References}

[1] M.B. Danah, \& B.E. Nicole, "Historical background and development of Social networking", Journal of Computer-Mediated Communication, vol. 23, no 13, pp. 210-230, 2008

[2] A. Adebiyi, M. Akinbode, S. Okuboyejo, G. Agboola, $\&$ A. Oni, "Social Networking and students' academic performance: the roles of attention deficit, predictors of behavior and academic competence," International Conference on African Development Issues (CU-ICAD): Information and Communication Technology Track, pp. 51-54, 2015.

[3] S. Livingstone, \& D. Brake, "On the rapid rise of social networking sites. New Finding and Policy Implication", vol. 24, no 1, pp. 75-83, 2010.

[4] M. Michikyan, K. Subrahmanyam, \& J. Dennis, "Facebook use and academic performance among college students: A mixed-methods study with a multi-ethnic Sample", Computer in Human Behaviour, vol. 45, no 1, pp. 265-272, 2015.

[5] J.A. Paul, H.A. Baker, \& J.D. Cochran, "Effect of online social networking on student academic performance," Computers in Human Behavior, vol. 28, no 6, pp.2117-2127, 2012.

[6] S. Rouis, M. Limayem, \& E. Salehi-Sangari, "Impact of Facebook Usage on Students' Academic Achievement: Role of Self-Regulation and Trust", Journal of Research in Educational Psychology, vol. 9, no 3, pp.961-994, 2011.

[7] P.A. Kirschner \& A.C. Karpinski, "Facebook and academic performance", Computers in Human Behavior, vol. 26, pp.1237-1245, 2010.

[8] O. Graham \& A. Kingsley, "Internet and social network relevance to academic", International Journal of Information and Communication Technology, vol. 2, no 12, pp. 55-60, 2005.

[9] R. Setzekorn, (2008). Social Networking Communities and E-Dating Services: Concepts and Implication. Rome: IGI Global Publishers.

[10] Y. Liu, "Social Media Tools as a Learning Resource," Journal of Educational Technology Development and Exchange, vol. 3, no 1, pp 101-114, 2010.

[11] L. Al-Shargi, K. Hashim, \& I. Kutbi, "Perception of social media impact on students' social behavior: A comparison between Arts and science students", 
International Journal of Education and Social science, vol. 2, no 4; April, 2015.

[12] H.A. Al-Tarawineh, "The influence of social networks on students' performance", Journal of Emerging Trends in Computing and Information Sciences, vol. 5, no 3, pp 200205, 2014.

[13] Q. Wang, W. Chen, \& Y. Liang, (2011). The Effects of Social Media on College Students. Johnson \& Wales University. Retrieved from http://scholarsarchive.jwu.edu/ cgi/viewcontent.cgi?article $=1004 \&$ context $=$ mba_student.

[14] A.R. Judilla, \& R.B. Gemora, "Influence of social networking on the study habits and performance of students in a state university", Journal of Social Science and Humanities Research, JSSHR 22, vol. 1, issue 2, pp. 112, 2015.

[15] B. Korzeny, "Impact of social networks on students' attitude in high schools", International Journal of Information Science, Engineering and Technology, vol. 5, no 15, pp 119-127, 2007.

[16] A.M. Oginni, V.Y. Awobodu, S.O. Saibu, \& M.O Alaka, "Impact of social networks on students' attitude, reading habits and learning outcomes in science classrooms. Canada International Conference on education, pp. 122-126, June, 2016.

[17] L. Hay, (2011). Social Networking Sites Affecting Students and their Study Habits.

[18] A. Ibrahim, “An assessment of students' attitude towards the use of social networks in science classroom", An Unpublished B.Sc.Ed Degree Project, Ekiti State Universty, Ado-Ekiti, Nigeria, 2015.

[19] S.A. Shehri, "Context in Our Pockets: Mobile Phones and Social networking as Tools of Contextualizing Language Learning", 10th World Conference on Mobile and Contextual Learning, 2011. 